\title{
Effect of Plant Extracts on Innate Immunity of Skin Cells: Investigations on Human Keratinocyte Cell Lines
}

Samiah Hamad Al-Mijalli ${ }^{* *}$, Barbara Plancot ${ }^{2}$

${ }^{1}$ Biology Department, College of Science, Princess Nourah bint Abdulrahman University, Riyadh, Saudi Arabia.

${ }^{2}$ Université de Rouen, Scientific Section, 76821 Mont saint Aignan, France.

\section{Abstract}

Stresses caused by many factors including pathogenic bacteria result in inflamatory diseases and they are considered as a major source of skin cancers and premature ageing.

Plants growing in semi-arid environments and deserts present the astonishing capacity to survive extreme conditions of drought and high temperatures. The objective of this study is to investigate the effects of extracts from two endemic plants from Saudi Arabia, namly C. myrrha and Rhamnus frangula, on the immune response of human keratinocyte cell lines $(\mathrm{Ha}-$ Ca'T).

Our major findings are i) the extracts from both plants exhibit a significant anti-oxidant activity. The concentrations used are below the limit value of toxicity. ii) These extracts stimulate the innate immune response in $\mathrm{HaCaT}$ cells and iii) treatments with these extracts are not harmful to the natural cutaneous microflora.

Together these findings are highly promising with regards to skin protection.

It was in this work investigate the impact of plant extracts on the immune response of human keratinocyte cell lines $(\mathrm{HaCaT})$. In this study, the elicitor activity of the extracts obtained from two endemic plants Arabia C. myrrha and R. frangula was evaluated. These plants were collected and provided by Dr. Samiah Hamad Al-Mijalli from (Saudia Arabia). The antioxidant activity of C. myrrba and R. frangula extracts was assessed for its ability to scavenge free radicals and to protect human keratinocytes from oxidative stress. Furthermore, the impact of such treatment was evaluated on both HaCaT cell viability and on the growth/proliferation of the natural cutaneaous microbiota.

Keywords: Bacteria; Commiphora Myrrha; Immunity; Rhamnus Frangula; Skin.

Abbreviations: A Chromophore Termed Bathocuproine (BATO); Commiphora myrrha (C. myrrha); Dulbecco's modified Eagle's medium (DMEM); Human keratinocyte cell lines (HaCaT); Oxygen Radical Absorbance Capacity (ORAC); Potent oxidant, 2,2_- azobis (2-amidinopropane) dihydrochlorid (AAPH); Rhamnus frangula (R. frangula); Reactive oxygen species (ROS); Total Anti-oxidant Capacity (TAC).

\section{Introduction}

The skin is a natural barrier between the body and the environment and is colonized by a large number of microorganisms. Environmental aggressions such as UV exposure, tobacco and pathogenic micro-organisms are known to have deleterious ef- fects on skin ultrastructure thus resulting in a loss of its protective function. Chronic or excessive environmental stresses lead to persistent inflamatory disease considered as a major source of skin cancers and premature ageing [4]. As a result of these various aggressions, the skin is constantly exposed to reactive oxygen species (ROS) production causing the so-called oxidative stress. ROS

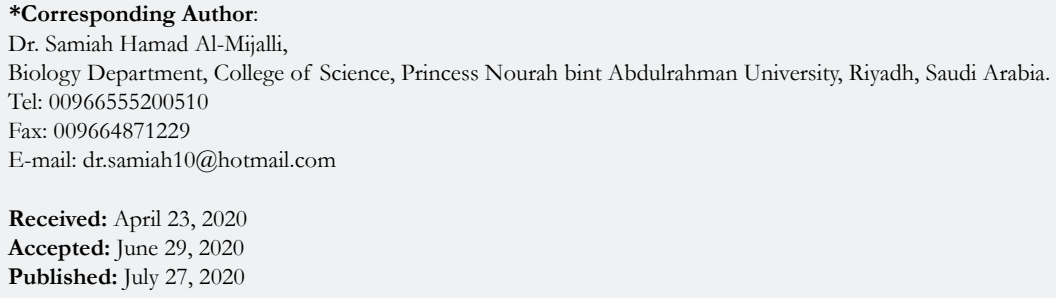

Citation: Samiah Hamad Al-Mijalli, Barbara Plancot. Effect of Plant Extracts on Innate Immunity of Skin Cells: Investigations on Human Keratinocyte Cell Lines. Int J Microbiol Adv Immunol. 2020;7(1):96-105. doi: http://dx.doi.org/10.19070/2329-9967-2000019 
are highly toxic to the skin layers, and ROS-mediated oxidative damage involves many biological molecules such as DNA modification (e.g., changes in DNA methylation), lipid peroxidation and secretion of inflammatory cytokines [7].

It has long been recognized that many naturally-occurring substances in plants have antioxidant activities [2]. Multipotent antioxidants are molecules that in addition to antioxidant activity possess pharmacological activitues. There are numerous examples of multipotent antioxidants among natural products. Besides their antioxidant properties, some natural antioxidants inhibit platelet-aggregation or display antineoplastic, anti-inflammatory and other activities [3]. The antioxidant activity of plant extracts is of particular interest both because of their beneficial physiological activity on human cells and the potential they have to replace synthetic antioxidants [6].

The objective of the present study is to take advantages of two endemic plants of Saudi Arabia and native to desert area. Such plants are known to be adapted to extreme environmental conditions and develop fascinating strategies to cope with both drought stress and extreme temperature. As a consequence, we postulated that these unexplored plants might be a source of new natural products that can potentially be used in cosmetic and dermatology.

\section{Material and Methods}

\section{Cells Culture}

HaCaT cells were cultured in Dulbecco's modified Eagle's medium (DMEM, Gibco®) upplemented with 10\% fetal bovin serum (FBS south american, Gibco ${ }^{\circledR}$ ) and 1\% penicillin-streptomycin at $37^{\circ} \mathrm{C}$ in a $5 \% \mathrm{CO}_{2}$ humidified atmosphere.

Briefly, the skin specimens were washed with DMEM, trypsinized $\left(0.25 \%\right.$ trypsin) at $37^{\circ} \mathrm{C}$ for $3 \mathrm{~min}$ to detach. Cells were collected and placed onto 96 . Keratinocytes were used for experiments at $60-80 \%$ of confluence.

Before all measurements/experiments, $\mathrm{HaCaT}$ cells were starved in DMEM without addition of FBS for $24 \mathrm{~h}$. The starvation conditions were necessary to uniform the experiments and exclude any undesired interference of serum components with cell response to the stimulus.

\section{ROS production by $\mathrm{HaCaT}$ cells in response to plant ex- tracts}

In situ detection of general ROS was performed by staining HaCaT cells cells with the probe CM- $\mathrm{H}_{2} \mathrm{DCFDA}$, which is nonfluorescent in its reduced form. In living cells, cell esterases convert CM-H2DCFDA into 2,7-dichlorodihydrofluorescein diacetate, which is subsequently oxidized by ROS into the fluorescent form 2,7-dichlorofluorescein in the presence of ROS. 2 104, maintained in Dulbecco's modified Eagle's medium (DMEM) with 10\% FBS under $5 \% \mathrm{CO}_{2}$ at $37^{\circ} \mathrm{C}$, were seeded in 96-well plates and grown for $24 \mathrm{~h}$ to let them attach to the bottom of the well. The cells were then incubated with different concentrations of hot water plant extracts at concentrations ranging from $0.031 \mathrm{mg} \cdot \mathrm{mL}^{-1}$ to $4 \mathrm{mg} \cdot \mathrm{mL}^{-1}$ to R. frangula and C. myrrha for $45 \mathrm{~min}$, and then incu- bated with $100 \mu \mathrm{L}$ of $5 \mu \mathrm{M}$ CM-H $\mathrm{D}_{2} \mathrm{DCFA}$. The fluorescence of the samples was thus measured at $535 \mathrm{~nm}$ (excitation $490 \mathrm{~nm}$ ), using the instrument (Flexstation 3, PRIMACEN), and from each measure the cell auto-fluorescence value was subtracted.

\section{Viability and proliferation of $\mathrm{HaCaT}$ cells in response to plant extracts}

Effects of stress exposures and their combination with hot water plants extracts on $\mathrm{HaCaT}$ cells growth and vitality as well as membrane integrity were assessed after $24 \mathrm{~h}$ by standard assays. The keratinocyte proliferation and cell survival was determined by MTT (3-[4,5-dimethylthiazol-2yl]-diphenyl tetrazolium bromide) colorimetric assay described elsewhere. The vitality and growth rate determinations were performed in triplicate for each experimental condition.

\section{TAC and ORAC Assays}

Both the assays were used to measure the total anti-oxidant power of the hot water plant extracts by "in vitro" reactions. The Total Anti-oxidant Capacity (TAC) assay is based on a redox reaction between a test compound and copper II, Cu (II). If a test compound has got reducing power, the $\mathrm{Cu}$ (II) is readily converted into $\mathrm{Cu}(\mathrm{I})$ which can be monitored by the addition of a chromophore termed Bathocuproine (BATO). Fifty $\mu$ l of hot water plant extracts solution in PBS (at concentrations ranging from 0.031 mg.mL-1 to 4 mg.mL $\mathrm{mL}^{-1}$ to R. frangula and C. myrrha ) was aliquoted into a 96-well plate. $50 \mu$ l of a BATO solution $(360 \mu \mathrm{M})$ was added to each well and the background absorbance at $490 \mathrm{~nm}$ was measured, then $25 \mu \mathrm{l}$ of $100 \mu \mathrm{M}$ CuSO 4 solution was added to each sample and incubated at room temperature for $30 \mathrm{~min}$. At the end of the incubation time, the absorbance at $490 \mathrm{~nm}$ was measured by a plate reader (Victor3, PerkinElmer). As reference standard, scalar dilutions of $\mathrm{CuCl}$ were used, ranging from 30 to $10 \mathrm{mM}$

Oxygen Radical Absorbance Capacity (ORAC) assay is based on the ability of a test compound to inhibit the oxidation of a fluorophore, generally fluorescein, by a potent oxidant, 2,2_- azobis (2-amidinopropane) dihydrochloride (AAPH). Twenty-five $\mu l$ of hot water plant extracts dilutions in phosphate buffer $75 \mathrm{mM}, \mathrm{pH}$ 7.4 (at concentrations ranging from $0.031 \mathrm{mg} \cdot \mathrm{mL}^{-1}$ to $4 \mathrm{mg} \cdot \mathrm{mL}^{-1}$ to R. frangula and C. myrrha) was aliquoted into 96-well plate and $150 \mu$ l of fluorescein solution $(2.5 \mathrm{nM}$ in phosphate buffer) was added to each sample. After incubation at $37{ }^{\circ} \mathrm{C}$ for $15 \mathrm{~min}, 25 \mu \mathrm{l}$ of AAPH solution ( $153 \mathrm{mM}$ in phosphate buffer) was pipetted into each well and the progress of the reaction monitored at 535 $\mathrm{nm}$, using a fluorescence multi-well reader. The fluorescence was measured every minute for $5 \mathrm{~min}$.

\section{Antioxidant capacity of plant extracts on $\mathrm{HaCaT}$ cells}

$210^{4} \mathrm{HaCa}$ T cells are maintained in Dulbecco's modified Eagle's medium (DMEM) with $10 \% \mathrm{FBS}$ under $5 \% \mathrm{CO}_{2}$ at $37^{\circ} \mathrm{C}$, were seeded in 96-well plates and grown for $20 \mathrm{~h}$ to let them attach to the bottom of the well. The cells were then incubated with different concentrations of hot water plant extracts or ascorbate $250 \mu \mathrm{M}$, used as positive control, for $2 \mathrm{~h}$. At the end, the cells were washed in PBS and the cell auto-fluorescence value (background) measured at the plate reader, using 490nm as excitation and $535 \mathrm{~nm}$ as emission wavelength. The cells were then incu- 
bated with the dye CM-H DCFDA (5-(and-6)-chloromethyl-2,7dichlorodihydrofluorescein diacetate, Invitrogen) at $37^{\circ} \mathrm{C}$ for 30 min. After an additional wash in PBS, the cells were treated with $\mathrm{H}_{2} \mathrm{O}_{2} 150 \mu \mathrm{M}$ and incubated for $30 \mathrm{~min}$. The fluorescence of the samples was thus measured at 535nm (excitation $490 \mathrm{~nm}$ ), using the instrument (Flexstation 3, PRIMACEN), and from each measure the cell auto-fluorescence value was subtracted.

\section{RNA extraction and reverse transcription}

Total RNA was extracted using an RNeasy mini kit (Qiagen) in accordance with the manufacturer's instructions. The RNA was eluted with $22 \mu \mathrm{l}$ of RNase-free water. DNase I treatment (RNase-Free DNase Set; Qiagen) was performed to remove contaminating genomic DNA. The quality of the RNA was assessed, and the quantity was estimated by nanodrop.

Approximately $1 \mu \mathrm{g}$ of RNA were reverse-transcribed in a $20 \mu \mathrm{l}$ reaction by High Capacity cDNA Reverse Transcription Kits (Applied biosystem) that contained 10X RT Buffer, 10X RT Random Primers, 25X dNTP Mix (100 mM), MultiScribe ${ }^{\mathrm{TM}}$ Reverse Transcriptase $50 \mathrm{U} / \mu \mathrm{L}$ and RNase Inhibitor.

\section{Quantitative real-time PCR amplification reactions}

Quantitative real-time PCR amplification reactions were performed using a 7500 Fast Realtime PCR System (Applied Biosystems) in a final reaction volume of $13 \mu \mathrm{l}$, which contained fast SYBR Green Master Mix (Applied Biosystems), $300 \mathrm{nM}$ forward and reverse primers and the template cDNA. The thermal cycling conditions involved a denaturation step at $95^{\circ} \mathrm{C}$ for $20 \mathrm{~s}$, followed by 40 cycles of amplification at $95^{\circ} \mathrm{C}$ for $3 \mathrm{~s}$ and $60^{\circ} \mathrm{C}$ for $30 \mathrm{~s}$. The final dissociation step was performed at $95^{\circ} \mathrm{C}$ for $15 \mathrm{~s}, 60^{\circ} \mathrm{C}$ for $1 \mathrm{~min}, 95^{\circ} \mathrm{C}$ for $15 \mathrm{~s}$ and $60^{\circ} \mathrm{C}$ for $15 \mathrm{~s}$.

\section{Results}

ROS production by $\mathrm{HaCaT}$ cells in response to plant extracts

To determine if treatment with plant extracts induced oxidative stress in keratenocytes $\mathrm{HaCaT}$, ROS production was monitored based on different concentrations with the probe CM-H DCFDA $_{2}$ able to detect all the ROS.

The hot water extract of $R$. frangula generates ROS in HaCaT cells. Moreover, production of ROS by HaCaT cells increases with increasing concentrations (figure 1). Indeed, after 60 minutes of treatment with $R$. frangula hot water extracts, a significant increase of ROS production is observed for the following concentrations $0.5 \mathrm{mg} \cdot \mathrm{mL}^{-1}, 1 \mathrm{mg} \cdot \mathrm{mL}^{-1}, 2 \mathrm{mg} \cdot \mathrm{mL}^{-1}, 3 \mathrm{mg} \cdot \mathrm{mL}^{-1}$ et $4 \mathrm{mg} \cdot \mathrm{mL}^{-1}$ compared with HaCaT cells treated with PBS (Phosphate Buffer saline) buffer only (figure 2). After two hours of treatment, the generation of ROS continues to increase to reach an equivalent fluorescence $200 \mathrm{AU}$, and 2 times higher than the PBS control (figure 2).

The hot water extract of C. myrrha gererate ROS in HaCaT cells within the first hour after treatment (figure 1). Moreover, the concentration increases and more production of ROS by HaCaT cells is observed. After 60 minutes of treatment with C. myrrha hot water extracts, a significant increase of ROS production is observed for the concentrations $0.5 \mathrm{mg} \cdot \mathrm{mL}^{-1}, 1 \mathrm{mg} \cdot \mathrm{mL}^{-1}, 2 \mathrm{mg} \cdot \mathrm{mL}^{-1}$, $3 \mathrm{mg} \cdot \mathrm{mL}^{-1}$ et $4 \mathrm{mg} \cdot \mathrm{mL}^{-1}$ compared to HaCaT cells treated with PBS (figure 2). However, after sixty minutes, the trend reverses. The hot water extract of $C$. myrrha does not induce the generation of ROS compared to HaCaT cells treated with the buffer PBS. After 120 min with the treatment PBS, the HaCaT cells produce much more ROS than $\mathrm{HaCaT}$ cells treated with the hot water extract of C. myrrha (figure 2).

Figure 1. Production of reactive oxygen species (ROS) in HaCat cells treated with at Commiphora myrrha and Rhamnus frangula extract. After tratement the amount of ROS produced in the cells measured by the fluroscent probe $\mathrm{CM}-\mathrm{H}_{2} \mathrm{DCF}$ DA. The values are means of 3 independent measures obtained from one reprasentative experiment.

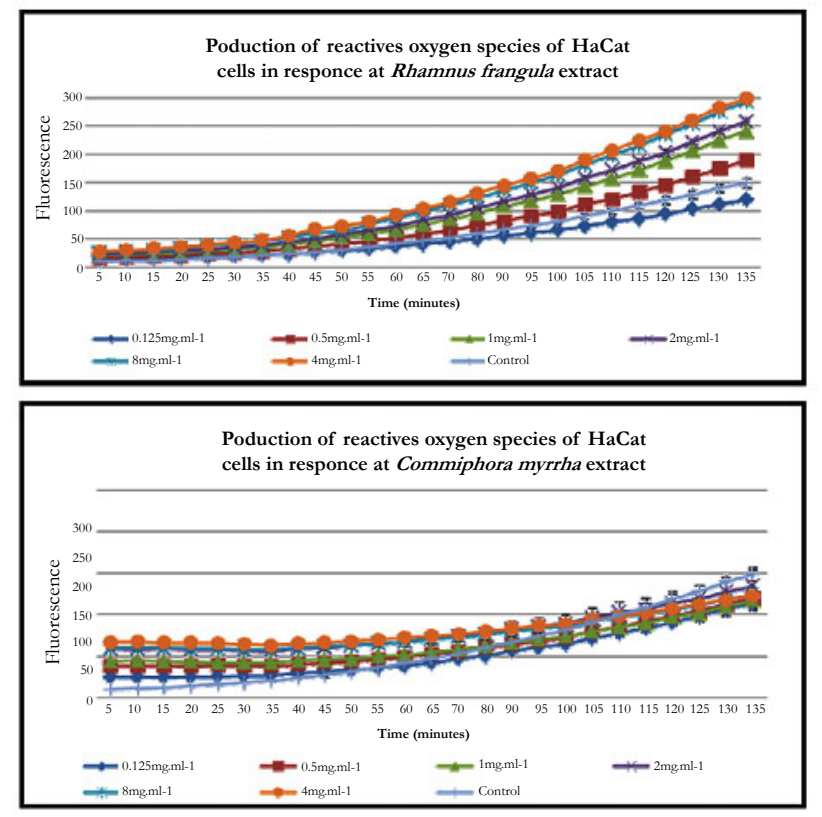


Figure 2. Production of reactive oxygen species (ROS) in HaCat cells treated with at Commiphora myrrha and Rhamnus frangula extract at 60 and 120 mins. After tratement the amount of ROS produced in the cells measured by the fluroscent probe $\mathrm{CM}-\mathrm{H}_{2}$ DCFDA. The values are means of 3 independent measures obtained from one reprasentative experiment.

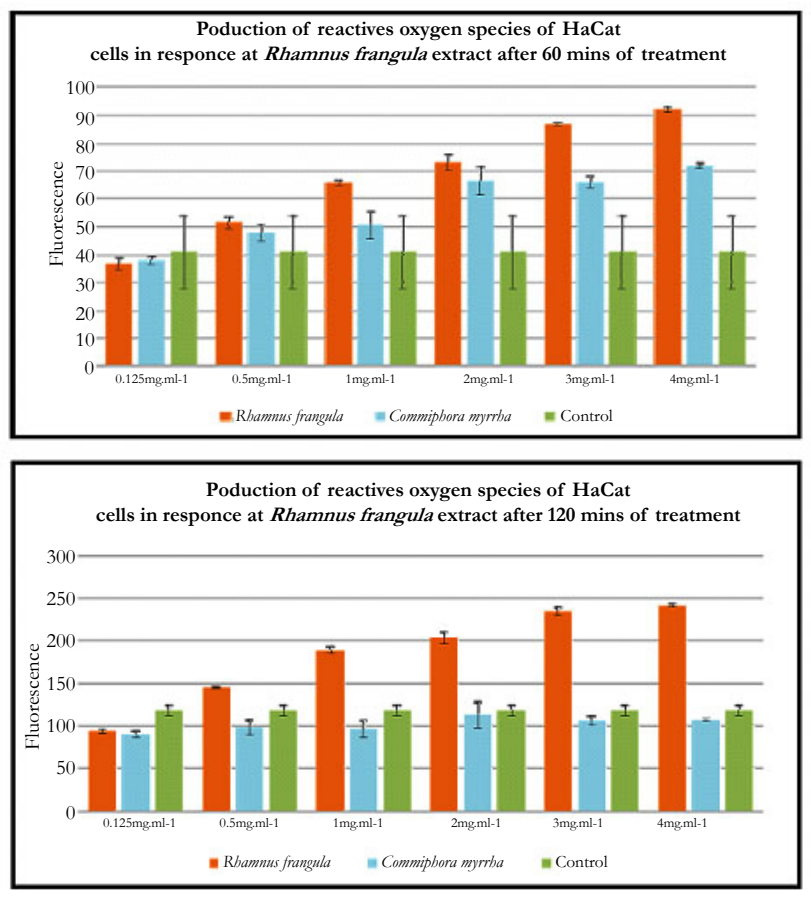

Viability and proliferation of $\mathrm{HaCaT}$ cells in response to plant extracts

In order to determine if the hot water of different plant extracts are cytotoxic to $\mathrm{HaCaT}$ cells, the cell viability and cell proliferation were determined by the MTT assay at different concentrations according to the method of Apone et al., [1].

Treatment with the hot water extract of $R$. frangula reduces the viability of the cells and proliferation at concentrations higher than $0.5 \mathrm{mg} \cdot \mathrm{mL}^{-1}$. However, concentrations below $0.5 \mathrm{mg} \cdot \mathrm{mL}^{-1}$ had no significant effect on the viability and proliferation of $\mathrm{HaCaT}$ cells. Treatment with the hot water extract of C. myrrha reduces the viability and proliferation at concentrations higher than $1 \mathrm{mg} \cdot \mathrm{mL}^{-1}$. However, concentrations below $1 \mathrm{mg} \cdot \mathrm{mL}^{-1}$ have no significant effect on the viability and proliferation of $\mathrm{HaCaT}$ cells (figure 3).

\section{Anti-oxydant activity of plant extracts}

In vitro assays: The anti-oxidant activity of a compound or a mixture of compounds depends on its total reducing capacity, on its ability to penetrate into the cells, and on its capacity to trigger a signal cascade leading to the production of endogenous anti-oxidant compounds in the cells. "In vitro" assays measure the reducing potential of the test material; however, they do not provide any information on the anti-oxidant induction in living cells.

Total Anti-oxidant Capacity (TAC): The Total Anti-oxidant Capacity (TAC) assay is based on a redox reaction between a test compound and copper II, Cu (II). If a test compound has a reducing power, the $\mathrm{Cu}$ (II) is readily converted into $\mathrm{Cu}$ (I) which can be monitored by the addition of a chromophore termed Bathocuproine (BATO).
For the hot water extracts of $\mathrm{R}$. frangula and $C$. myrrha different concentrations (ranging from $0.062 \mathrm{mg}$.mL-1 to $4 \mathrm{mg}$.mL-1) were mixed with $100 \mathrm{mM}$ of $\mathrm{Cu}$ (II) and BATO, and after 30 min the amount of $\mathrm{Cu}(\mathrm{I})$ produced was measured at $490 \mathrm{~nm}$.

For the concentrations ranging from $0.062 \mathrm{mg} \cdot \mathrm{mL}^{-1}$ to $0.5 \mathrm{mg} \cdot \mathrm{mL}^{-1}$ of the hot water extract of $R$. frangula, the quantity of mmol of $\mathrm{Cu}(\mathrm{I})$ produced per liter remains constant and is equivalent to 25 mmol. However, with increasing concentrations of $R$. frangula hot water extracts, the quantity of $\mathrm{Cu}(\mathrm{I})$ product per liter increases to reach $45 \mathrm{mmol}$ at a concentration of $4 \mathrm{mg} \cdot \mathrm{ml}^{-1}$. In the presence of the PBS (control), the amount of mmol of $\mathrm{Cu}(\mathrm{I})$ produced is equivalent to zero.

For the concentrations, ranging from $0.062 \mathrm{mg} \cdot \mathrm{mL}^{-1}$ to $4 \mathrm{mg} \cdot \mathrm{mL}^{-1}$ of the hot water extract of C. myrrha, the quantity of mmol of $\mathrm{Cu}(\mathrm{I})$ produced per liter increased in relation with the concentrations used to reach $42 \mathrm{mmol}$ at a concentration of $4 \mathrm{mg} \cdot \mathrm{ml}^{-1}$. In the presence of the PBS (control), the amount of mmol of $\mathrm{Cu}(\mathrm{I})$ produced is equivalent to zero (figure 4).

Oxygen Radical Absorbance Capacity (ORAC): Oxygen Radical Absorbance Capacity (ORAC) assay is based on the ability of a test compound to inhibit the oxidation of a fluorophore, generally fluorescein, by a potent oxidant, 2, 2- azobis (2-amidinopropane) dihydrochloride (AAPH). The standard is a powerfull anti-oxidant, the trolox (vitamin $\mathrm{E}$ ) with the concentration ranging from $0.5 \mu \mathrm{M}$ to $20 \mu \mathrm{M}$.

For the hot water extract of $\mathrm{R}$. frangula at the concentration of $0.031 \mathrm{mg} \cdot \mathrm{mL}^{-1}$, the values are comprised between the curves of the trolox equivalent to $5 \mu \mathrm{M}$ and $8 \mu \mathrm{M}$. Thus, the antioxidant activity of hot water extracts of $\mathrm{R}$. frangula is equivalent to the concentration of trolox $5-8 \mu \mathrm{M}$. At the concentration 0.062 $\mathrm{mg} \cdot \mathrm{mL}^{-1}$ the curve is located after the curves of the trolox equiva- 
Figure 3. Cytotoxic effects of Rhamnus frangula and Commiphora myrtha extract extracts on HaCaT cells. Cells were teated with the exctacts for $72 \mathrm{~h}$. Cell viability was measured by the MTT assay. Data are averages of triplicate determinations.

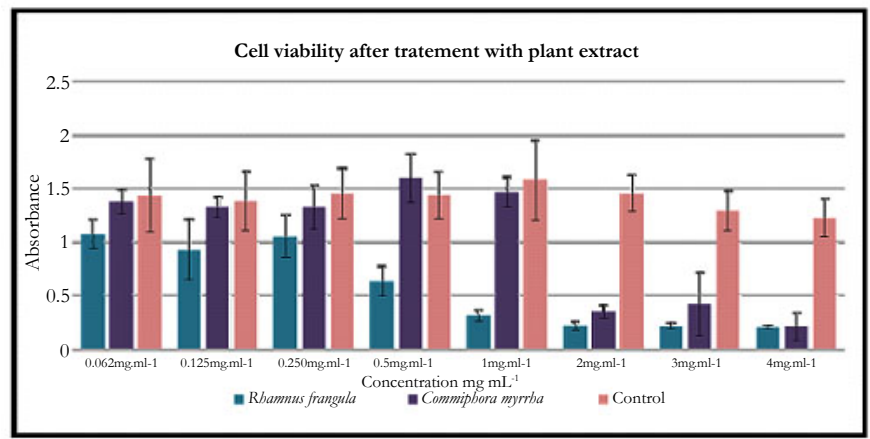

Figure 4. Standard curve for total anti-Oxidant Capacity (b) Total anti-oxidant power of Rhamnus frangula and Commiphora myrrha extract measured by Total Anti-oxidant Capacity (TAC) assays. Six different caocentrations of the plant extract were analyzed for their anti-oxidant power by using the Total Anti-oxidant Capacity (TAC) assay. The values reported exported in the graphs are avarages of three independent measures and the error bars represent standard deviations.
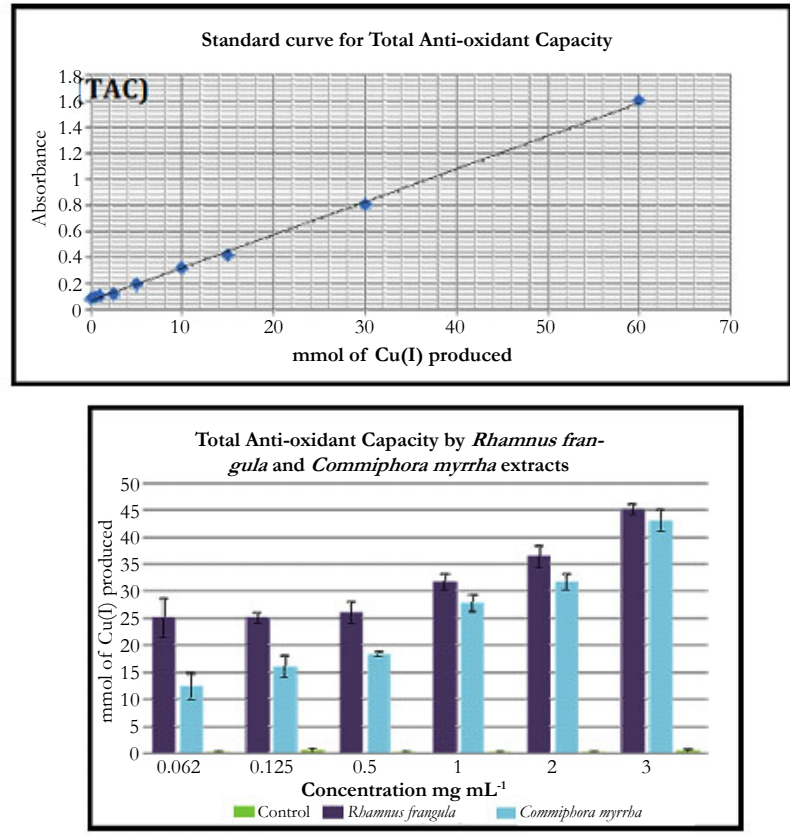

lent to $10 \mu \mathrm{M}$. Thus, the antioxidant power of hot water extract of $R$. frangula is equivalent to the concentration of trolox higher at $10 \mu \mathrm{M}$ of trolox (figure 5).

For the hot water extract of C. myrrha at the concentration of $0.125 \mathrm{mg} \cdot \mathrm{mL}^{-1}$ and $0.250 \mathrm{mg} \cdot \mathrm{mL}^{-1}$, the curve is located between the curves of the trolox equivalent to $0.5 \mu \mathrm{M}$ and $5 \mu \mathrm{M}$. Thus, the antioxidant power of hot water extract of $\mathrm{R}$. frangula is equivalent to the concentration of trolox 0.5-5 $\mu \mathrm{M}$ (figure 5).

2 In vivo assays: To evaluate the protective anti-oxidant effect of the plant extract on the HaCaT cells, we treated the cells with eight different concentrations of the mixture before being stressed by $\mathrm{H}_{2} \mathrm{O}_{2}$.

For the hot water extract of $R$. frangula ranging from $4 \mathrm{mg} \cdot \mathrm{mL}^{-1}$ to $0.250 \mathrm{mg} \cdot \mathrm{mL}^{-1}$, a strong reduction of ROS production by $\mathrm{HaCaT}^{-}$ cells was observed compared to the untreated sample. For the concentration ranging from $0.125 \mathrm{mg} \cdot \mathrm{mL}^{-1}$ to $0.062 \mathrm{mg} \cdot \mathrm{mL}^{-1}$ a little reduction of ROS production was observed compared to the untreated sample (figure 6). Indeed, after 60 minutes of treat- ment, a strong reduction in the production of ROS is observed for concentrations ranging from 4 to $0.250 \mathrm{mg} \cdot \mathrm{ml}-1$ (figure 7). However, after 120 minutes of treatment a sharp decline in the production of ROS is observed for concentrations ranging from 4 to $1 \mathrm{mg} \cdot \mathrm{mL}^{-1}$ (figure 7 ). It could be that the antioxidant capacity of the $R$. frangula hot water extract has been consumed at the level of the low concentrations.

For the hot water extract of C. myrrha, a strong reduction of ROS production was observed compared to the untreated sample only for the concentration at $4 \mathrm{mg} \cdot \mathrm{ml}^{-1}$. For the other concentration (3 to $\left.0.062 \mathrm{mg} \cdot \mathrm{mL}^{-1}\right)$, there is no reduction of ROS production by $\mathrm{HaCa} \mathrm{T}$ cells (figure 6). Indeed, after 60 minutes and 120 minutes, a decrease in the production of ROS is observed only for the highest concentration $\left(4 \mathrm{mg} \cdot \mathrm{mL}^{-1}\right)$ (figure 7 ).

\section{Microbial activity of plant extracts}

The bright field microscopy of skin microbial flora shows the presence of bacteria in cluster or in diplococcic (figure 8). These morphologies of bacteria suggest they belong to the genus Staph- 
Figure 5. Total anti-oxidant power of Rhamnus frangula and Commiphora myrrha extract measured by Oxygen Radical Absorbance Capacity (ORAC) assays. Six different caocentrations of the plant extract were analyzed for their anti-oxidant power by using the ORAC assay. The values reported exported in the graphs are avarages of three independent measures. The arrows represent the samples.

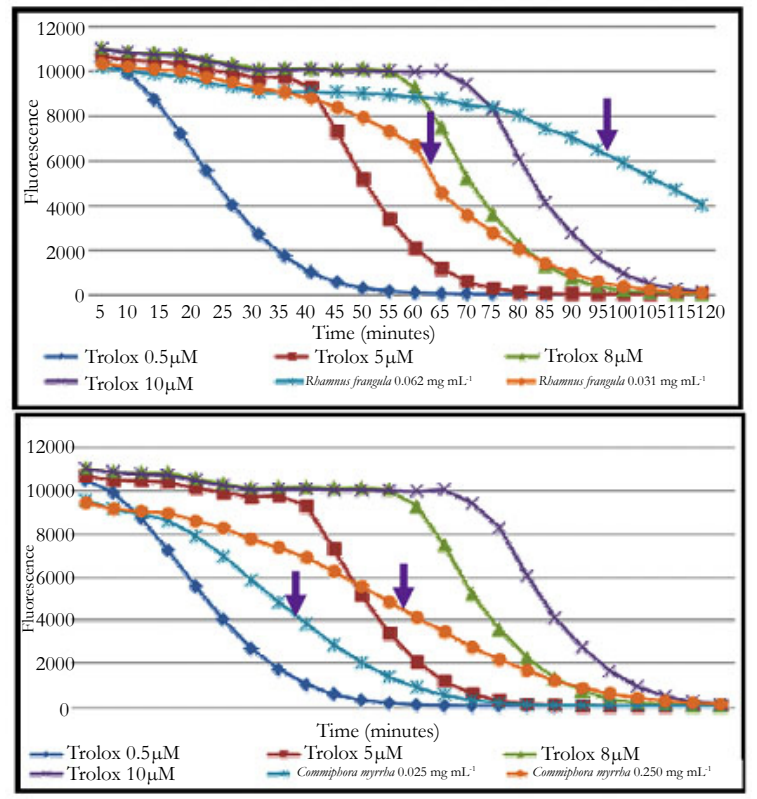

Figure 6. Anti-oxidant effect of Rhamnus frangula and Commiphora myrrha extract against $\mathrm{H}_{2} \mathrm{O}_{2}$ on $\mathrm{HaCat}_{\text {cells. }}$

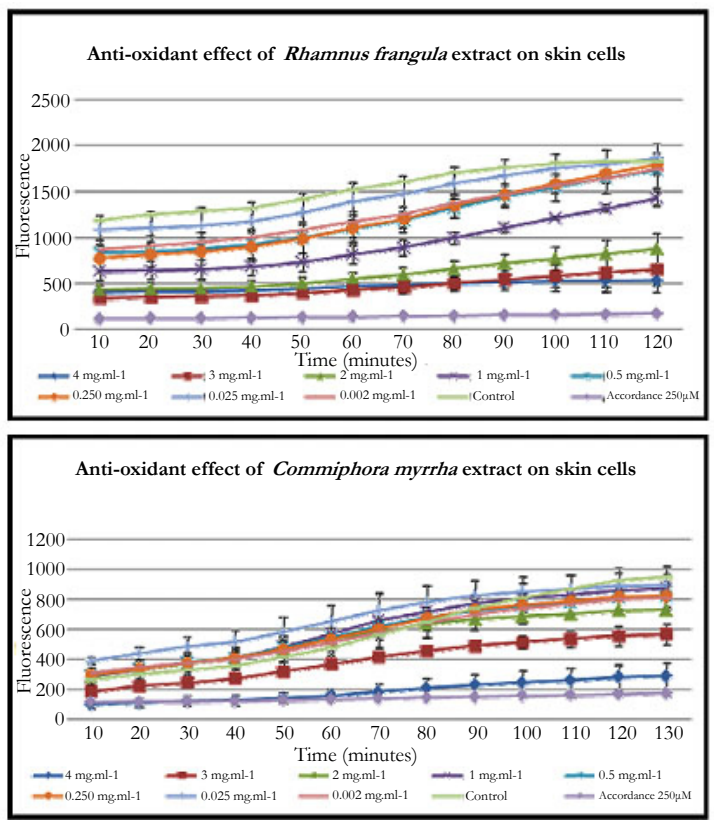

ylococcus and Streptococcus.

The microbial activity of the plant extracts of $\mathrm{R}$. frangula and $C$. myrrha were studied in vitro with different concentrations $(0.25$, $0.5,1,2$, and $3 \mathrm{mg} / \mathrm{ml}$ ) against skin microbial flora.

The enumeration of bacteria shows a strong increase in proliferation of skin microbial flora treated with $0.25 \mathrm{mg} \cdot \mathrm{ml}^{-1}$ hot water extract of $R$. frangula compared to untreated samples (figure 9). For the concentration ranging from $0.5 \mathrm{mg} \cdot \mathrm{mL}^{-1}$ to $3 \mathrm{mg} \cdot \mathrm{mL}^{-1}$, the concentration of bacteria is equivalent to that of untreated samples.

The enumeration of bacteria shows an increase in skin microbial flora growth treated with $0.25 \mathrm{mg} \cdot \mathrm{ml}^{-1}$ hot water extract of $C$. myrrha compared to untreated samples (figure 9). For the concentration ranging from $0.5 \mathrm{mg} \cdot \mathrm{mL}^{-1}$ to $3 \mathrm{mg} \cdot \mathrm{mL}^{-1}$, the concentration of bacteria is equivalent to that of the samples treated with 0.25 mg. $\mathrm{ml}^{-1}$ of hot water extract of C. myrrha. The treatment with 1 $\mathrm{ml}$ of ethanol is the negative control.

Effects of plant extract on defense gene activation in $\mathrm{Ha}$ CaT cells

In order to investigate whether hot plant extract activate defense gene markers in $\mathrm{HaCaT}$ cells, we examined the expression changes of some selected genes in response to extracts from $\mathrm{R}$. frangula and C. myrrha at $0.25 \mathrm{mg} \cdot \mathrm{ml}^{-1}$ over a time course by real-time 
Figure 7. Anti-oxidant effect of Rhamnus frangula and Commiphora myrrha extract against $\mathrm{H}_{2} \mathrm{O}_{2}$ on $\mathrm{HaCat}$ cells after 60 and 120 minutes of treatment.
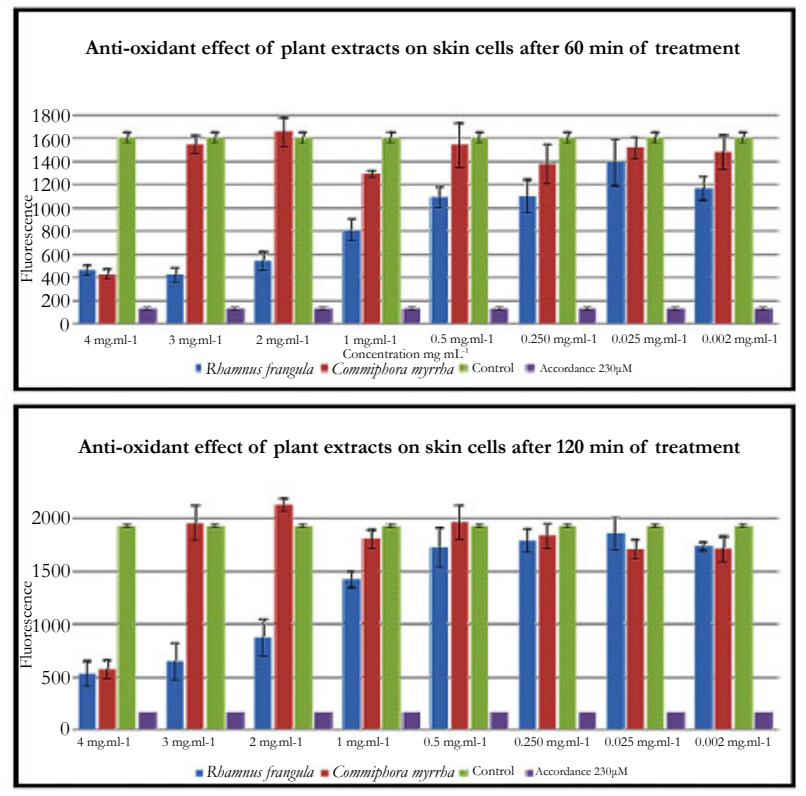

Figure 8. Bright field microscopy of skin microbial flora.

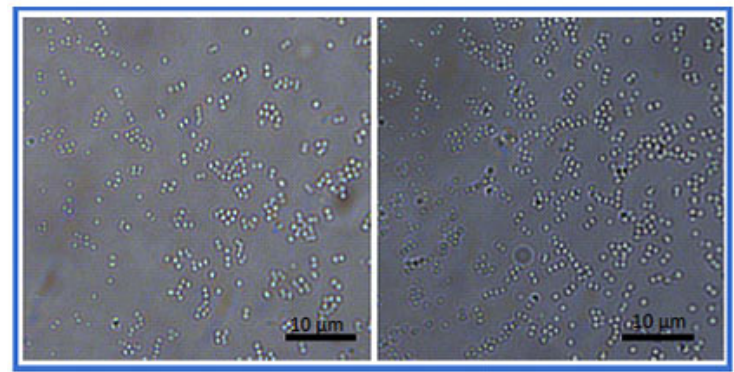

Figure 9. The enumeration in in vivo of skin microbial flora treated with Rhamnus frangula and Commiphora myrrha extract. After treatment, the concentration ofskin microbial flora increase.

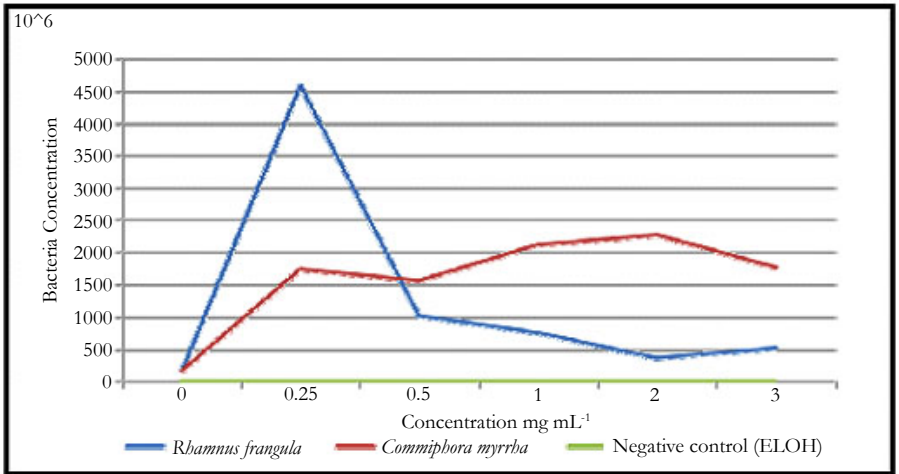

quantitative reverse transcription (qR'T)-PCR (figure 10). We have chosen this concentration because it is a non-lethal concentration to the cells.

For this study we have selected five genes: CATALASE (CAT), SUPEROXIDE DISMUTASE (SOD), KERATIN1 (KER1), DEFENSIN1 (DEF1), INTERLEUKIN (S100A). The gene CAT encoding a catalase that is important for protecting the cells from oxidative damage caused by the ROS. After treatment with the extracts from both $\mathrm{R}$. frangula and C. myrrha, the expression of CAT gene is not induced (figure 11 and 12). The SOD gene encodes for an enzyme that catalyses the dismutation of superoxide $\left(\mathrm{O}_{2}^{-}\right)$into oxygen and hydrogen peroxide. Thus, they are an im- portant antioxidant defense in nearly all cells exposed to oxygen. After treatment with hot plant extract of $\mathrm{R}$. frangula, we observe a reduction in SOD transcript at 1, 3, 6, $12 \mathrm{~h}$ after elicitation (figure 11). After treatment with hot plant extract of $C$. myrrbaan increase in SOD transcript at $1 \mathrm{~h}$ after elicitation (figure 12). The KER1 gene is a differentiation factor. The protein encoded by this gene is a member of the keratin gene family. The type II cytokeratins consist of basic or neutral proteins that are arranged in pairs of heterotypic keratin chains coexpressed during differentiation of simple and stratified epithelial tissues $[5,8]$. This gene is down regulated at 24, $48 \mathrm{~h}$ after treatment with hot plant extract of $R$. frangul and C. myrrha. An induction of DEFENSINE 1 gene, one of the most important genes known to encode for a peptide with 
Figure 10. Procedure to ectraction of RNA in HaCat cells after treatment with hot water extract of Rhamnus frangula and Commiphora myrrha at $1 \mathrm{~h}, 3 \mathrm{~h}, 6 \mathrm{~h}, 12 \mathrm{~h}$ and $48 \mathrm{~h}$ compared at $\mathrm{HaCat}$ cells untreated.

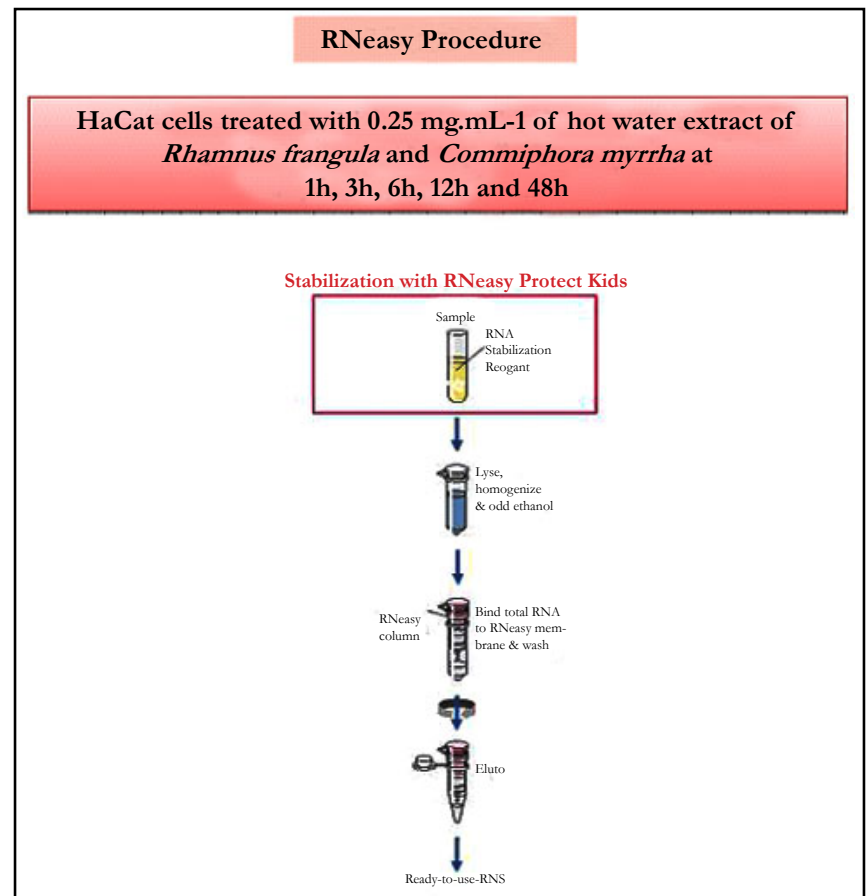

Figure 11. Relative expression levels of CAT, SOD, KER1, DEF1 and S100A in HaCat cells in responce to hot water extract of Rhamnus frangula. hpt, Hours post treatment, Gene expression values are presented as relative expression. The reference genes used in this study are $A C T I N$ and $G A P D C$.

CAT: CATALASE, DEF: DEFENSINE1, hours post treatment, KER1: KERATINE, S100A: INTERLEUKIN, SOD: SU-

\section{PEROXIDEDISMUTASE}

T: untreated

T: treated with the extract.

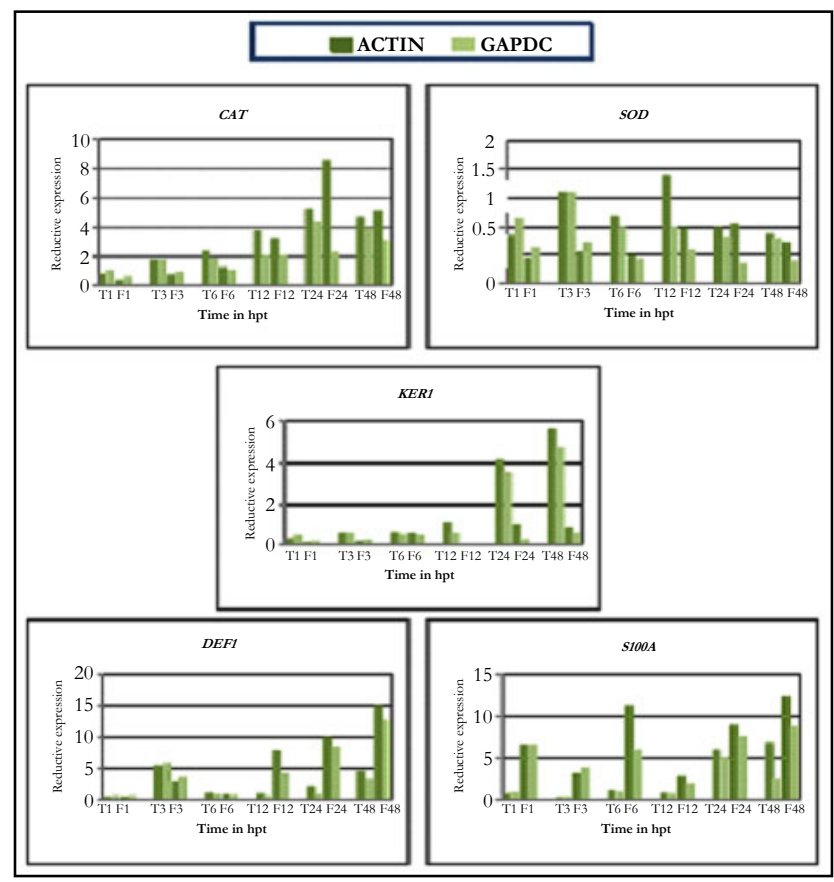

a strong antimicrobial activity occurs. This human defensin is upregulated from 12, 24, $48 \mathrm{~h}$ after elicitation with hot plant extract of R. frangula treatment (figure 11) and is up-regulated from $1 \mathrm{~h}$ with hot plant extract of C. myrrha (figure 12). The gene S100A gene encoding an interleukin that participate in the regulation of immune responses, inflammatory reactions. After treatment with hot plant extract of $\mathrm{R}$. frangula, we observed an up-regulation at $1,3,6,12,24,48 \mathrm{~h}$ after treatment (figure 11). After treatment with hot plant extract of C. myrrha an increase in S100A transcript at $1 \mathrm{~h}$ after elicitation (figure 12).

\section{Discussion}

The protective effects of extracts from both plants ( $R$. frangula and C. myrrha ) endemic to Saudi Arabia were assessed on HaCaT cells. ROS production is a well known marker of stress response. 
Figure 12. Relative expression levels of $C A T, S O D, K E R 1, D E F 1$ and S100A in HaCat cells in responce to hot water extract of $C$. myrrha. hpt, Hours post treatment, Gene expression values are presented as relative expression. The reference genes used in this study are $A C T I N$ and $G A P D C$.

CAT: CATALASE, DEF: DEFENSINE1, hours post treatment, KER1: KERATINE, S100A: INTERLEUKIN, SOD: SUPEROXIDEDISMUTASE

\section{T: untreated}

T: treated with the extract.

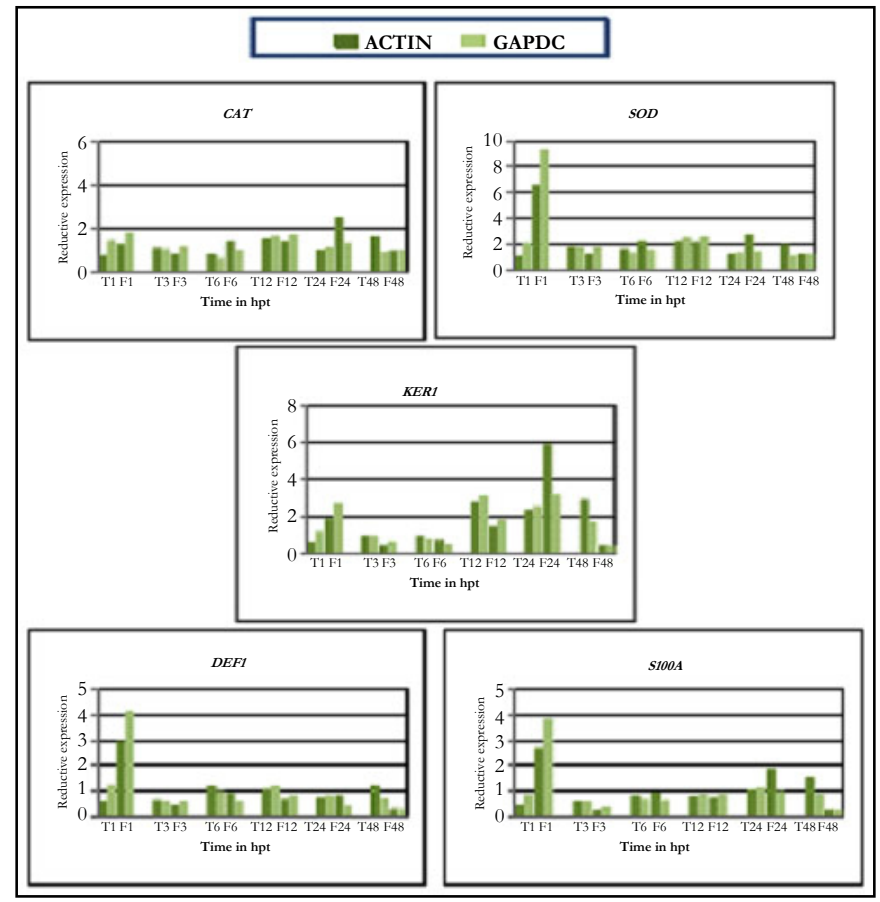

In order to determine whether plant extracts are able to trigger an immune response in $\mathrm{HaCaT}$ cells, ROS formation was monitored using the fluorescent probe $\mathrm{CM}-\mathrm{H}_{2}$ DCFDA.

Extracts of both plants triggered ROS formation in HaCaT cells. The hot water extracts from $\mathrm{R}$. frangula and C. myrrba gererate ROS in $\mathrm{HaCaT}$ cells within the first hour after treatment. However, the intensity of the response was more important regarding the hot water extract from R. frangula as compared to C. myrrha. These findings reveal that extracts from these two saoudian plants are able to stimulate an immune response in $\mathrm{HaCaT}$ cells.

The next step was to determine the range of concentration the most appropriate for using these products as elicitors. In order to determine if the plants extracts are cytotoxic to HaCaT cells, cell viability and proliferation were determined by the MTT assay, according to the method of Apone et al[1,8]. For the R. frangula extract, a loss of cell viability and proliferation occurred at concentrations higher than $0.5 \mathrm{mg} \cdot \mathrm{mL}^{-1}$. The C. myrrba extract reduces the viability and proliferation at concentrations higher than 1 $\mathrm{mg} \cdot \mathrm{mL}^{-1}$. As a consequence, these products should not be used at such higher concentrations. We consider that these extracts from R. frangula and C. myrrba are not suitable for use as potential elicitors. Indeed the concentration required to induce ROS is higher than the toxicity value.

However, to rule out the possibility that the fluorescent probe CM- $\mathrm{H}_{2}$ DCFDA is not sufficiently sensitive in the cell system investigated, expression of defense gene markers was investigated in $\mathrm{HaCaT}$ cells in response to $0.25 \mathrm{mg} \cdot \mathrm{ml}^{-1}$ treatment of extract from R. frangula and C. myrrba. The expression of selected marker genes was monitored in response to extracts from $\mathrm{R}$. frangula and C. myrrba at $0.25 \mathrm{mg} \cdot \mathrm{ml}^{-1}$ over a time course by real-time quantitative reverse transcription (qRT)-PCR. Surprisingly, the extracts from both $\mathrm{R}$. frangula and C. myrrha induce expression of defense genes in $\mathrm{HaCaT}$ cell at such concentration. Moreover, the extract from $R$. frangula induces the expression of more strongly defence gene than extract from $C$. myrrha. These data confirmed that the fluorescent probe $\mathrm{CM}-\mathrm{H}_{2} \mathrm{DCFDA}$ was not sensitive enough to detect ROS production in response to low concentration of plant extracts.

As a consequence, based on (qRT)-PCR data, extracts from $R$. frangula and $C$. myrrba could be potential elicitors to trigger immune response in $\mathrm{HaCaT}$ cells.

We investigated the potential property of these fractions to be used as anti-oxidant molecules. To determine the anti-oxidant capacity of the hot water extract of $\mathrm{R}$. frangula and C.myrrha we performed the two following in vitro tests: The Total Anti-oxidant Capacity (TAC) and Oxygen Radical Absorbance Capacity (ORAC). Additionally, an in vivo assay was performed. Our findings reveal that the different plant extracts have a strong in vitro anti-oxidant capacity. For the anti-oxidant effect of $\mathrm{R}$. frangula and C. myrrha $\mathrm{H}_{2} \mathrm{O}_{2}$ on $\mathrm{HaCaT}$ cells both plant extracts protect the cell against the adverse effects of $\mathrm{H}_{2} \mathrm{O}_{2}$. Interestingly, our findings reveal that both plant extracts could be used as potential antioxidant molecules against oxidative stress. It should be noted that concentrations used are very low and below the limit value for toxicity.

To evaluate the effect of the hot water extract of $R$. frangula and 
C. myrrha skin microbial flora, we have performed one test in vitro. The microbial activity of both plant extracts were studied in vitro at different concentrations $(0.25,0.5,1,2$, and $3 \mathrm{mg} / \mathrm{ml})$ against skin microbial flora. The enumeration of bacteria shows a strong increase in skin microbial flora growth treated with $0.25 \mathrm{mg} \cdot \mathrm{ml}^{-1}$ hot water extract of $R$. frangula compared to the non-treated flora. The enumeration of bacteria shown an increase in skin microbial flora growth treated with $0.25 \mathrm{mg} \cdot \mathrm{ml}^{-1}$ hot water extract of $C$. myrrha compared to the skin microbial flora untreated. Thus, the different plant extracts used here are not harmful to the natural cutaneous microbial flora.

The results obtained with extracts from two endemic plants of Saudi Arabia R. frangula and C. myrrha are highly promising with regards to skin protection.

The limit value for toxicity of the extracts from $R$. frangula and $C$. myrrha is $0.5 \mathrm{mg} \cdot \mathrm{mL}-1$ and $1 \mathrm{mg} \cdot \mathrm{mL}-1$ respectively.

Both extracts have a significant anti-oxidant activity. Therefore these extracts could be used as potential anti-oxidant molecules against oxidative stress. It is worth noting that concentrations used are below the limit value for toxicity.

The extracts have no negative effect for the natural cutaneous microflora.

\section{Acknowledgement}

This research was funded by the Deanship of Scientific Research at Princess Nourah bint Abdulrahman University through the Fast-track Research Funding Program.

\section{References}

[1]. Apone F, Tito A, Carola A, Arciello S, Tortora A, Filippini L, et al. A mixture of peptides and sugars derived from plant cell walls increases plant defense responses to stress and attenuates ageing-associated molecular changes in cultured skin cells. Journal of Biotechnology. 2010; 145: 367-376. PMID: 20018216.

[2]. Cui Y, Kim D-S, Park K-C. Antioxidant effect of Inonotus obliquus. Journal of Ethnopharmacology. 2005; 96: 79-85. PMID: 15588653.

[3]. Kosalec I, Kremer D, Locatelli M, Epifano F, Genovese S, Carlucci G, et al. Anthraquinone profile, antioxidant and antimicrobial activity of bark extracts of Rhamnus alaternus, R. fallax, R. intermedia and R. pumila. Food Chemistry. 2013; 136: 335-341. PMID: 23122067.

[4]. Pastore S, Lulli D, Potapovich AI, Fidanza P, Kostyuk VA, Dellambra E, et al. Differential modulation of stress-inflammation responses by plant polyphenols in cultured normal human keratinocytes and immortalized $\mathrm{Ha}$ CaT cells. Journal of Dermatological Science. 2011; 63: 104-114. PMID: 21620684.

[5]. Seo SJ, Ahn SW, Hong CK, Ro BI. Expressions of $\beta$-defensins in human keratinocyte cell lines. Journal of Dermatological Science. 2001; 27: 183-191. PMID: 21620684.

[6]. Stef D-S, Iosif G, Ioan-Trasca T, Stef L, Pop C, Harmanescu M, et al. Evaluation of 33 medicinal plant extracts for the antioxidant capacity and total phenols. Journal of Food, Agriculture \& Environment. 2010; 8: 207-210.

[7]. Thongrakard V, Tencomnao T. Modulatory effects of Thai medicinal plant extract on proinflammatory cytokines-induced apoptosis in human keratinocyte HaCaT cells. African Journal of Biotechnology. 2013; 9: 4999-5003.

[8]. Walker D, Sun T, Macneil S, Smallwood R. Modeling the Effect of Exogenous Calcium on Keratinocyte and HaCaT Cell Proliferation and Differentiation Using an Agent-Based Computational Paradigm. Tissue Engineering. 2006; 12: 2301-2309. PMID: 16968170. 